\title{
Characterization of Inorganic Elements in Woody Biomass Bottom Ash from a Fixed-bed Combustion System, a Downdraft Gasifier and a Wood Pellet Burner by Fractionation
}

\author{
Adrian. K. James ${ }^{1}$, Steve S. Helle ${ }^{1}$, Ronald W. Thring ${ }^{1}$, Gurkaran S. Sarohia ${ }^{1}$ \& P. Michael Rutherford ${ }^{1}$ \\ ${ }^{1}$ Environmental Science \& Engineering, University of Northern British Columbia, 3333 University Way, Prince \\ George, BC, V2N 4Z9, Canada \\ Correspondence: Adrian. K. James, Environmental Science \& Engineering, University of Northern British \\ Columbia, 3333 University Way, Prince George, BC, V2N 4Z9, Canada. E-mail: ajames@unbc.ca
}

Received: February 26, 2014

Accepted: April 1, 2014 Online Published: May 28, 2014

doi:10.5539/eer.v4n1p85

URL: http://dx.doi.org/10.5539/eer.v4n1p85

\begin{abstract}
The direct combustion of biomass residues produces large quantities of bottom ash. Environmental sustainable management requires that ash recycling should be carried out whenever possible. Suitable applications of bottom ash are based predominantly on its chemical properties. The presence of major ash forming and trace elements along with other intrinsic properties unique to bottom ash, suggest its potential as a soil additive. But, ash quality must be of a high standard to prevent environmental pollution. This comparative study characterizes bottom ash obtained from three types of bioenergy systems - a fixed-bed boiler, a downdraft gasifier and a wood pellet burner. The chemical properties were analyzed and discussed for each bottom ash, together with their respective particle fractions that were obtained by sieving. The $\mathrm{pH}$ of the starting ash samples for the gasifier, boiler and pellet burner were 10.36, 12.49 and 13.46, respectively. Ni with a concentration of $229 \mathrm{mg} / \mathrm{kg}$ in the pellet burner ash, exceeded the maximum limit for soil amendments (in British Columbia, Canada) within the particle size fraction $\geq 850 \mu \mathrm{m}$ but $<2000$. All samples were significantly enriched in both $\mathrm{Ca}(50-61 \%)$ and $\mathrm{K}(10-26 \%)$. The elements $\mathrm{Mg}, \mathrm{Al}, \mathrm{Mn}, \mathrm{Fe}, \mathrm{P}$ and $\mathrm{Na}$ each contributed $10 \%$ or less to the inorganic portion of the ash. Concentrations of inorganic contents varied with particle size. Water soluble phosphates were very low in the samples. The results suggest that size fraction separation can be a useful method to isolate fractions containing higher (or lower) amounts of some metals. This method may be a useful technique for managing ash that contains elements exceeding environmental limits.
\end{abstract}

Keywords: bottom ash, soil amendment, major elements, trace elements, particle size fraction, ash utilization

\section{Introduction}

The employment of wood combustion technologies have resulted in a rapid increase in the use of woody-biomass residues for energy production. Boilers, gasifiers and pellet burners are but some of the systems available for wood energy production. A disadvantage of using biomass for energy production is that large amounts of residual ash are generated (Dahl, Nurmesniemi, Poykio, \& Watkins, 2010). Ash from these combustion processes vary in quality depending on the fuel type, operating conditions of the system and the type of combustion system (Obernberger, Biedermann, Widmann, \& Riedl, 1997). Ideally, biomass ash should be recycled whenever possible, but large amounts of wood ash are typically landfilled (Picco, February 2010). Countries such as Sweden and the United States of America (USA) use landfills to dispose majority of their ash (Clarholm, 1994; Vance, 1996; Demeyer, Voundi-Nkana, \& Velow, 2001). The quality of the ash in part determines recycling options; some options such as land spreading require low trace element concentrations to prevent environmental pollution (Pels, de Nie, \& Kiel, 2005). The application of wood ash to soils may counteract soil acidification and correct for nutrient deficiencies; this is widely used in regions that carry out extensive forest harvesting, such as Northern Europe and parts of North America (Demeyer et al., 2001; Stupak, Asikainen, Roser, \& Pasanen, 2008; Aronsson \& Ekelund, 2004). In Canada, biomass ash is mainly landfilled but land applications are more common in some provinces than others. In British Columbia the use of ash as for soil applications is relatively limited due to current provincial regulations. Until adequate research is carried out the majority of ash generated in B.C. may be limited to landfilling or other uses outside of soil applications. 
Limiting factors for the use of wood ash in soils include trace element concentrations and potential organic pollutants (Sarenbo, 2009; Knapp \& Insam, 2011). Elevated concentrations of trace elements in ashes may limit utilization of ash in soils and therefore also the recycling of nutrient elements (e.g. $\mathrm{Ca}, \mathrm{Mg}, \mathrm{K}, \mathrm{P}$ ), too. The handling and application of ash is improved by hardening or aggregation; but, ash with a high organic $\mathrm{C}$ content does not harden properly (Narodoslawsky \& Obernberger, 1996).

The physical and chemical characteristics of wood ash may vary with particle size fraction (Dahl et al., 2010; Liao, $\mathrm{Wu}$, \& Yan, 2007; James, Thring, Helle, \& Rutherford, 2013). Particle size fractions high in undesirable trace element concentrations could be separated from some ashes, thereby improving the overall quality of the residual ash material (and therefore improving recycling options). Previous research shows that arsenic concentrations in fly ash exceeded the Finnish environmental limits for the particle size fraction less than $0.125 \mathrm{~mm}$ (Dahl et al., 2010). Particle separation may be carried out by sieve fractionation and may influence variables such as trace element concentrations, $\mathrm{pH}$, organic carbon concentration, bulk density and other chemical-physical properties.

Should the properties vary significantly in particle size fractions, greater applications of ash as a soil amendment or as a raw material for products requiring specific properties could be employed. Ash-producing industries may find this particularly useful when considering disposal or utilization methods for ash.

The objective of this research was to characterize ash from the three systems. A comparative study of the chemical properties of each bottom ash, as well as their respective fractions, obtained by sieving, was carried out. This paper will identify the inorganic elemental distribution of specific particle size fractions, $\mathrm{pH}$ and anion distribution of boiler, gasifier and wood pellet burner bottom ash. It is hoped that these results will assist in finding specific applications for bottom ash.

\section{Experimental}

Wood ash from from three types of combustion systems, a fixed-bed boiler (Canfor Pulp Mill), a downdraft gasifier (University of Northern British Columbia - UNBC) and a wood pellet burner (UNBC) were used in the study. The downdraft fixed bed gasifier is capable of producing power of $5 \mathrm{MW}$, the wood pellet burner $0.4 \mathrm{MW}$ and an industrial scale fixed bed boiler, $27 \mathrm{MW}$. The fuel for the gasifier and boiler is hog fuel comprised predominantly of softwood sawmill waste and is primarily derived from pine wood. The pellet burner utilizes wood pellets made locally from soft-wood saw dust. Two ash samples were collected from each system. The boiler ash sample was collected on April 27, 2012 - BA. The gasifier ash sample was collected July 18, $2012-$ GA. Pellet burner samples was collected March 5, 2010 - PA. Henceforth, the boiler sample is denoted as BA, gasifier sample GA and pellet burner sample, PA. The ash samples were separated into different particle fractions as follows.

\subsection{Particle Size Distribution}

Approximately $100 \mathrm{~g}$ of air-dried starting ash original sample obtained from boiler, gasifier, or pellet burner was separated into different size fractions using a stack of 5 sieves $(2000 \mu \mathrm{m}, \mathrm{x} 850 \mu \mathrm{m}, 425 \mu \mathrm{m}, 250 \mu \mathrm{m}, 150 \mu \mathrm{m})$, arranged in decreasing diameter openings (Hermann \& Baker, 2002). Ash was poured on the top sieve (largest opening), which was then covered; the sieve stack was then placed on an automatic shaker for 15 minutes after which the stack was removed. Each sieve with the retained material was gently tapped on the sides before being removed from the stack and weighed. Retained ash was removed and stored, while the sieve trays were thoroughly cleaned and reweighed to obtain the mass of ash retained on tray. The analyses were repeated twice and an average of the results taken. The following retained fractions were used for subsequent analyses: starting wood-ash, $\geq 2000 \mu \mathrm{m}, \geq 850 \mu \mathrm{m}$ but $<2000 \mu \mathrm{m}, \geq 425 \mu \mathrm{m}$ but $<850 \mu \mathrm{m}, \geq 250 \mu \mathrm{m}$ but $<425 \mu \mathrm{m}, \geq 150 \mu \mathrm{m}$ but less than $250 \mu \mathrm{m}$ and $<150 \mu \mathrm{m}$.

For reporting data purposes, the fractions will be denoted as $2000 \mu \mathrm{m}, 850 \mu \mathrm{m}, 425 \mu \mathrm{m}, 250 \mu \mathrm{m}, 150 \mu \mathrm{m}$ and < $150 \mu \mathrm{m}$. Each of the retained fractions were weighed and then stored for further analysis.

\section{2 pH Analysis}

The $\mathrm{pH}$ of ash fractions were determined following methods described in (Kalra \& Maynard, 1991). The $\mathrm{pH}$ was measured potentiometrically using the $\mathrm{pH}$ of saturated paste method. A $400 \mathrm{ml}$ beaker was half-filled with ash, then sufficient deionized water was added to saturate sample. The sample was mixed and subsequently left to sit for 1 hour after which $\mathrm{pH}$ readings were taken. Analysis of all fractions were repeated twice and an average of the results taken.

\subsection{Concentration and Distribution of Trace Elements and Major Ash-Forming Elements}

Selected elements within each fraction were determined by ICP-MS at UNBC. $300 \mathrm{mg}$ of sample was mixed 
with $10 \mathrm{~mL}$ conc. $\mathrm{HNO}_{3}$ and then diluted to $50 \mathrm{~mL}$ with deionized water. This sample mixture was then subjected to microwave digestion, using a Milestone MLS 1200 Mega digestion system. Metal characterization was done by an inductively coupled plasma (ICP-MS) on an Agilent 7500 ICPMS machine. This was used to determine the alkali, alkali earth and trace elements.

\subsection{Anion Analysis}

Anion concentrations were determined using the Dionnex IC-5000 system. Ten (10) $\mathrm{mL}$ of deionized water was added to $\sim 400 \mathrm{mg}$ of samples and shaken for $12 \mathrm{hrs}$. The samples were then removed from shaker and centrifuged for $15 \mathrm{~min}$, after which $\sim 2 \mathrm{~mL}$ of sample was obtained for analysis using Ion chromatography. All results shown are considered to be only water soluble amounts. Duplicate analyses were conducted and an average concentration reported.

\section{Results}

\subsection{Particle Size Distribution of Ash}

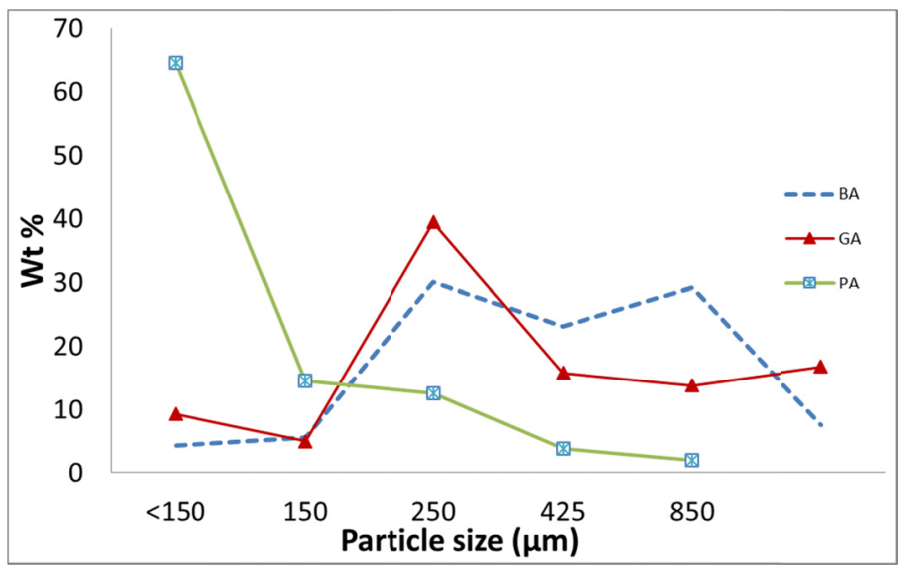

Figure 1. Retained Weight as a function of particle size distribution for boiler ash (BA), gasifier ash (GA) and pellet burner ash (PBA) samples (Data referenced) (James et al., 2013)

Table 1. Total carbon contents and $\mathrm{pH}$ of bottom ash samples of boiler, gasifier and pellet burner

\begin{tabular}{cccccccc}
\hline & \multicolumn{3}{c}{$*$ Carbon } & & \multicolumn{3}{c}{$\mathrm{pH}$} \\
\cline { 1 - 3 } \cline { 6 - 8 } Particle & BA & GA & PA & & BA & GA & PA \\
size $/ \mu \mathrm{m}$ & wt.\% & wt.\% & wt.\% & & & \\
\hline$<150$ & 17.17 & 3.67 & 5.75 & & 12.22 & 10.43 & 13.53 \\
150 & 13.85 & 6.11 & 36.08 & & 12.56 & 10.41 & 13.36 \\
250 & 21.56 & 3.24 & 19.16 & & 12.12 & 10.36 & 13.20 \\
425 & 52.76 & 5.76 & 6.62 & & 10.74 & 10.28 & 12.13 \\
850 & 66.41 & 3.71 & 5.94 & & 10.49 & 10.05 & 11.16 \\
2000 & 70.73 & 3.07 & & & 10.41 & 9.69 & \\
Starting ash & 51.79 & 5.13 & 5.64 & & 12.49 & 10.36 & 13.46 \\
\hline
\end{tabular}

*Data referenced from (Hermann \& Baker, 2002) and on a dry basis.

\section{2 pH Analysis}

Table 1 shows the distribution of the $\mathrm{pH}$ for the PA, GA and BA samples. Ash from all three systems was high in $\mathrm{pH}$ but recorded different $\mathrm{pH}$ readings. Ash from the gasifier was the least alkali, followed by the boiler then the pellet burner. The starting ash samples for the gasifier, boiler and pellet burner were 10.36, 12.49 and 13.46 respectively. It was observed that the $\mathrm{pH}$ increased for all ash samples as the particle size fraction decreased, with the exception of the particle size fractions $<150 \mu \mathrm{m}$ for the for BA. The increase in $\mathrm{pH}$ may have been due to the increase in concentrations of the alkali earth metals (refer to Table 4) as the particle size fractions decreased potentially leading to higher concentrations base-forming metal salts. 
Table 2. Concentration and distribution of trace elements for samples of boiler, gasifier and pellet burner bottom ash (dry basis)

\begin{tabular}{lrrrrrrrrr}
\hline Particle Size $(\mu) \mathrm{m}$ & $\begin{array}{r}\mathrm{Cr} \\
\mathrm{mg} / \mathrm{kg}\end{array}$ & $\begin{array}{r}\mathrm{Cu} \\
\mathrm{mg} / \mathrm{kg}\end{array}$ & $\begin{array}{r}\mathrm{Ni} \\
\mathrm{mg} / \mathrm{kg}\end{array}$ & $\begin{array}{r}\mathrm{Pb} \\
\mathrm{mg} / \mathrm{kg}\end{array}$ & $\begin{array}{r}\mathrm{V} \\
\mathrm{mg} / \mathrm{kg}\end{array}$ & $\begin{array}{r}\mathrm{Co} \\
\mathrm{mg} / \mathrm{kg}\end{array}$ & $\begin{array}{r}\mathrm{Mo} \\
\mathrm{mg} / \mathrm{kg}\end{array}$ & $\begin{array}{r}\mathrm{As} \\
\mathrm{mg} / \mathrm{kg}\end{array}$ & $\begin{array}{r}\mathrm{Cd} \\
\mathrm{mg} / \mathrm{kg}\end{array}$ \\
\hline PA & & & & & & & & & \\
850 & 49.58 & 61.23 & 229.59 & 7.22 & 14.70 & 6.74 & 3.13 & 0.49 & 0.50 \\
425 & 47.32 & 108.91 & 175.40 & 3.55 & 15.03 & 6.90 & 3.55 & 0.80 & 1.91 \\
250 & 79.91 & 135.53 & 109.48 & 4.17 & 14.30 & 7.67 & 4.01 & 0.85 & 3.69 \\
150 & 52.09 & 153.60 & 69.70 & 2.07 & 12.85 & 7.54 & 4.52 & 0.84 & 4.45 \\
$<150$ & 52.38 & 170.72 & 40.65 & 2.74 & 10.18 & 7.93 & 5.24 & 0.98 & 9.46 \\
Starting ash & 54.13 & 132.47 & 54.50 & 0.44 & 10.55 & 7.20 & 4.82 & 0.92 & 7.71 \\
\hline Gasifier ash & & & & & & & & & \\
2000 & 23.40 & 16.66 & 20.00 & 0.63 & 29.37 & 5.29 & 0.48 & 1.39 & 0.03 \\
850 & 12.81 & 37.75 & 19.09 & 7.36 & 21.95 & 4.17 & 1.15 & 1.76 & 0.04 \\
425 & 18.54 & 31.30 & 27.23 & 1.72 & 20.71 & 4.63 & 0.74 & 1.40 & 0.07 \\
250 & 35.33 & 60.97 & 68.13 & 5.12 & 29.65 & 7.35 & 4.30 & 6.31 & 0.30 \\
150 & 44.54 & 66.37 & 67.74 & 4.10 & 28.57 & 7.04 & 3.33 & 4.85 & 0.31 \\
$<150$ & 47.57 & 207.57 & 78.81 & 4.20 & 33.41 & 7.86 & 5.33 & 7.49 & 0.44 \\
Starting ash & 33.51 & 43.38 & 60.74 & 1.64 & 28.53 & 6.78 & 4.13 & 5.42 & 0.27 \\
\hline Boiler ash & & & & & & & & & \\
2000 & 5.84 & 34.01 & 6.89 & 3.34 & 3.50 & 1.56 & 1.51 & 0.52 & 2.21 \\
850 & 4.64 & 81.52 & 6.31 & 9.59 & 4.14 & 1.86 & 1.40 & 0.69 & 2.85 \\
425 & 10.36 & 50.42 & 11.06 & 7.09 & 12.16 & 3.23 & 1.61 & 1.14 & 4.11 \\
250 & 19.87 & 77.59 & 19.05 & 9.99 & 18.54 & 5.17 & 2.29 & 1.82 & 6.18 \\
150 & 30.00 & 107.49 & 25.07 & 9.00 & 24.49 & 6.70 & 2.71 & 2.07 & 6.18 \\
$<150$ & 28.97 & 419.58 & 25.36 & 13.86 & 24.66 & 6.99 & 2.79 & 2.37 & 7.52 \\
Starting ash & 11.82 & 32.85 & 13.39 & 4.89 & 12.44 & 3.79 & 1.88 & 1.45 & 4.76 \\
\hline *nvironmental Limits & 1060 & 2200 & 180 & 500 & & 150 & 20 & 75 & 20 \\
\hline$*$ Enving & & & & & & & & &
\end{tabular}

*Environmental limit's for ash intended for land application in B.C., Canada (BC Ministry of Environment, 2008).

\subsection{The Concentration and Distribution of Elements in Ashes and Anion Distribution}

\subsubsection{Trace Elements}

The concentrations of elements for the starting ash and within specific particle size fractions of $\mathrm{Cr}, \mathrm{Cu}, \mathrm{Ni}, \mathrm{Pb}, \mathrm{V}$, $\mathrm{Co}, \mathrm{Mo}$, As and $\mathrm{Cd}$ are shown in Table 3.2. Of the starting ash samples analysed, $\mathrm{Cu}$ from the Pellet burner system was highest in trace element concentration; $132 \mathrm{mg} / \mathrm{kg}$ for $\mathrm{Cu}$ (Table 3.2). Cu was enriched in pellet burner ash by $\sim 3$ and $\sim 4$ times that of the gasifier and the boiler samples, respectively. The elements $\mathrm{Ni}$ and $\mathrm{Cr}$ followed next in concentrations, ranging from $33-55 \mathrm{mg} / \mathrm{kg}$ for the pellet burner and gasifier starting ash. The boiler samples were $\sim 5$ times lower than the pellet burner ash in both $\mathrm{Ni}$ and $\mathrm{Cr}$ contents. In most results, the boiler samples were slightly lower in trace metal concentrations. All elements in the starting ash fractions of the 3 ash samples were well within the British Columbia soil amendment limits (BC Ministry of Environment, 2008).

Table 2 also shows the distribution of trace elements within particle size fractions for the respective ash. For most elements, a slight increase in concentration was observed as the particle size fraction decreased in all ash types. All fractions for each element were within the environmental limits for soil amendments in British Columbia, except the $850 \mu \mathrm{m}$ fraction of $\mathrm{Ni}$, obtained from the pellet burner ash; concentration of $229 \mathrm{mg} / \mathrm{kg}$. While not exceeding the limit, the $425 \mu \mathrm{m}$ fraction also had a high concentration of $176 \mathrm{mg} / \mathrm{kg} \mathrm{Ni}$. It is evident that some elements are more concentrated in specific fractions of ash. The results suggest that fraction separation can be a useful method to isolate fractions containing higher amounts of some metals. This method may be a useful technique for isolating elements exceeding environmental exposure limits and at the same time rendering the residual ash useful. 
Table 3. Percent total metal distribution in boiler, gasifier and pellet burner ash

\begin{tabular}{llll}
\hline Elements & $\begin{array}{l}\text { BA } \\
\text { wt.\% }\end{array}$ & $\begin{array}{l}\text { GA } \\
\text { wt.\% }\end{array}$ & $\begin{array}{l}\text { PA } \\
\text { wt.\% }\end{array}$ \\
\hline $\mathrm{Ca}$ & 60 & 61 & 55 \\
$\mathrm{~K}$ & 15 & 10 & 21 \\
$\mathrm{Mg}$ & 6 & 6 & 11 \\
$\mathrm{Al}$ & 4 & 7 & 2 \\
$\mathrm{Mn}$ & 4 & 3 & 6 \\
$\mathrm{Fe}$ & 3 & 6 & 1 \\
$\mathrm{P}$ & 3 & 3 & 2 \\
$\mathrm{Na}$ & 2 & 2 & 1 \\
Remaining & 2 & 2 & 1 \\
elements & & & \\
\hline
\end{tabular}

Table 4. The concentration of major ash forming elements within particle size fractions for boiler, gasifier and pellet burner on a dry basis

\begin{tabular}{|c|c|c|c|c|c|c|c|c|}
\hline Particle Size $(\mu) \mathrm{m}$ & $\begin{array}{l}\mathrm{Ca} \\
\mathrm{mg} / \mathrm{kg}\end{array}$ & $\begin{array}{l}\mathrm{Al} \\
\mathrm{mg} / \mathrm{kg}\end{array}$ & $\begin{array}{l}\mathrm{Mg} \\
\mathrm{mg} / \mathrm{kg}\end{array}$ & $\begin{array}{l}\mathrm{Na} \\
\mathrm{mg} / \mathrm{kg}\end{array}$ & $\begin{array}{l}\mathrm{K} \\
\mathrm{mg} / \mathrm{kg}\end{array}$ & $\begin{array}{l}\mathrm{P} \\
\mathrm{mg} / \mathrm{kg}\end{array}$ & $\begin{array}{l}\mathrm{Mn} \\
\mathrm{mg} / \mathrm{kg}\end{array}$ & $\begin{array}{l}\mathrm{Fe} \\
\mathrm{mg} / \mathrm{kg}\end{array}$ \\
\hline \multicolumn{9}{|l|}{ PA } \\
\hline 850 & 136392 & 9266 & 25062 & 1607 & 61751 & 3880 & 11185 & 9973 \\
\hline 425 & 195843 & 10538 & 35162 & 2756 & 99339 & 6606 & 16921 & 9055 \\
\hline 250 & 239720 & 9758 & 46113 & 3459 & 112781 & 8109 & 22630 & 8883 \\
\hline 150 & 253148 & 9193 & 51437 & 3414 & 105948 & 8264 & 25198 & 7993 \\
\hline$<150$ & 262728 & 7555 & 56533 & 2854 & 95660 & 8551 & 28115 & 6168 \\
\hline Starting ash & 246186 & 7689 & 50910 & 2851 & 95232 & 8075 & 25845 & 6659 \\
\hline \multicolumn{9}{|l|}{ GA } \\
\hline 2000 & 20910 & 11888 & 4966 & 4966 & 5006 & 932 & 854 & 12652 \\
\hline 850 & 19848 & 9897 & 4213 & 4213 & 9120 & 1083 & 1018 & 10707 \\
\hline 425 & 27422 & 11904 & 5363 & 5363 & 12933 & 1382 & 1509 & 11911 \\
\hline 250 & 140745 & 16083 & 13992 & 13992 & 20778 & 6955 & 7267 & 12732 \\
\hline 150 & 112986 & 16250 & 12220 & 12220 & 20677 & 5569 & 6072 & 12903 \\
\hline$<150$ & 167030 & 15936 & 15733 & 15733 & 18430 & 8178 & 8463 & 12814 \\
\hline Starting ash & 124946 & 14852 & 12308 & 12308 & 20077 & 6026 & 6522 & 12339 \\
\hline \multicolumn{9}{|l|}{ BA } \\
\hline 2000 & 46393 & 2427 & 4518 & 2456 & 25997 & 2086 & 2693 & 1558 \\
\hline 850 & 51562 & 2728 & 4946 & 2548 & 25342 & 2419 & 2971 & 1797 \\
\hline 425 & 62728 & 6208 & 6450 & 2466 & 22548 & 3057 & 3615 & 4732 \\
\hline 250 & 122267 & 10015 & 12189 & 2616 & 22393 & 6481 & 7229 & 7613 \\
\hline 150 & 153376 & 12080 & 14939 & 2786 & 20800 & 8259 & 9084 & 10131 \\
\hline$<150$ & 166787 & 12079 & 16256 & 2788 & 21529 & 9144 & 10084 & 9756 \\
\hline Starting ash & 92564 & 6763 & 8974 & 2507 & 23354 & 4846 & 5394 & 5186 \\
\hline
\end{tabular}

\subsubsection{Major Elements General Trends (Starting Ash)}

Table 3 displays the percent of total ash forming elements in each ash sample. These percentages were obtained by taking the sum of all the total metal content found in $1 \mathrm{~kg}$ (d.b) of ash. All samples were significantly enriched in both $\mathrm{Ca}(50-61 \mathrm{wt} . \%)$ and $\mathrm{K}(10-26 \mathrm{wt} . \%)$. The high weight percent metal content found in these ash are expected 
for woody biomass ash. The elements $\mathrm{Mg}, \mathrm{Al}, \mathrm{Mn}, \mathrm{Fe}, \mathrm{P}$ and $\mathrm{Na}$ each contributed $10 \%$ or less to the total elemental portion of the ash. The other inorganic elements present in ash, though not mentioned in the table cumulatively contributed $2 \%$ or less to the total metal content of the ash under study and are not discussed in this paper. All analysis were based on the top eight most concentrated elements $\mathrm{Ca}, \mathrm{K}, \mathrm{Mg}, \mathrm{Al}, \mathrm{Mn}, \mathrm{Fe}, \mathrm{P}$ and $\mathrm{Na}$.

The elements $\mathrm{Al}, \mathrm{P}, \mathrm{Mg}, \mathrm{Mn}, \mathrm{Na}, \mathrm{Fe}, \mathrm{K}$, and $\mathrm{Ca}$ are shown in Table 4. The table shows that the concentration of $\mathrm{P}$, $\mathrm{Mn}, \mathrm{Mg}, \mathrm{K}$ and $\mathrm{Ca}$ were found to be higher in pellet burner ash when compared to the other two ash types. The elements $\mathrm{Al}, \mathrm{Fe}$, and $\mathrm{Na}$ were present in higher quantities in the gasifier ash when compared to the other two ash types. Additionally, the pellet burner ash contained $\sim 4$ times higher concentrations of $\mathrm{K}, \mathrm{Mg}$ and $\mathrm{Mn}$, than the other ash types. However, Ca was only $\sim 2$ times higher in pellet ash. Some degree of variation in concentrations is expected due to the likely variation of fuel types, temperatures and other factors. Research has shown that calcium concentrations increase at temperatures below $900{ }^{\circ} \mathrm{C}$ which is primarily due to the decomposition of calcium carbonates (Misra, Ragland, \& Baker, 1993). Above $900{ }^{\circ} \mathrm{C}$, the Ca concentration also increases due to the dissociation and volatilization of potassium oxide formed after dissociation. The variation in oxide and/or carbonate concentrations bound to the ash will affect the concentration of the elements in samples when concentration is calculated on a weight basis.

\subsubsection{Major Elements General Trends (within Fraction)}

Within fractions, it was observed that $\mathrm{P}, \mathrm{Mg}, \mathrm{Mn}, \mathrm{Na}$, and $\mathrm{Ca}$ either increased with decreasing particle size or remained relatively constant. Ca was highest in concentration within each fraction and for all ash types (Table 4). The highest values reported for Ca were seen in Pellet burner ash, from $\sim 136,000$ to $\sim 262,000 \mathrm{mg} / \mathrm{kg}$ moving from fractions $850 \mu \mathrm{m}$ to $<150 \mu \mathrm{m}$. Additionally, $\mathrm{K}$ was found to be highest in the pellet burner ash, containing concentrations ranging from $\sim 62,000$ to $\sim 112000 \mathrm{mg} / \mathrm{kg}$ when moving from $850 \mu \mathrm{m}$ to $250 \mu \mathrm{m}$ fractions. While most of the elements were present in higher quantities in pellet burner ash as compared to other ash types, $\mathrm{Al}, \mathrm{Na}$ and $\mathrm{Fe}$ were present in higher concentrations in gasifier ash.

The concentration of each element not only varies across different systems but within fractions as well. This variation in concentrations poses a difficulty in the general application of bottom ash to soils due to the lack of standardization in ash quality. According to Obernberger and Supancic (2009), ash recycling to agricultural lands can help reduce the use of artificial fertilizers and close the natural mineral cycle. This is largely due to the presence of N, P and K in biomass ash. However, Pels et al. (2005) suggests that the use of biomass ash as a soil fertilizer is limited due to a number of deficiencies in ash. The author noted that biomass ash can only be a source of $\mathrm{K}$ because ash from thermal sources is low in $\mathrm{N}$ and the $\mathrm{P}$ present has a very low solubility at soil conditions. In previous research on the same ash, the ultimate analysis showed $\mathrm{N}$ content all less than $1 \mathrm{wt} . \%$ on a dry basis for all ash samples (James et al., 2013). Wood naturally has low N contents. Furthermore, due to the conversion of most of the wood $\mathrm{N}$ to $\mathrm{NH}_{3}, \mathrm{NO}_{\mathrm{x}}$ and/or $\mathrm{N}_{2}$ during the combustion of the wood, it is expected that the nitrogen content be low (Misra et al., 1993; Steenari, Karlsson, \& Lindqvist, 1999; Knapp \& Insam, 2011).

Table 5. The concentration (dry ash basis) of water soluble phosphates relative to particle size distribution for boiler gasifier and pellet burner ash

\begin{tabular}{llll}
\hline $\begin{array}{l}\text { sieve size/ } \\
\mu \mathrm{m}\end{array}$ & $\begin{array}{l}\mathrm{BA} \\
\mathrm{mg} / \mathrm{kg}\end{array}$ & $\begin{array}{l}\mathrm{GA} \\
\mathrm{mg} / \mathrm{kg}\end{array}$ & $\begin{array}{l}\mathrm{PA} \\
\mathrm{mg} / \mathrm{kg}\end{array}$ \\
\hline$<150$ & - & 0.23 & 0.66 \\
150 & - & 0.1 & 1.87 \\
250 & - & 0.22 & 1.67 \\
425 & 0.35 & 0.32 & 3.64 \\
850 & 2.57 & 0.15 & 0.29 \\
2000 & 2.29 & 0.74 & \\
$\mathrm{AR}$ & - & 0.08 & 0.83 \\
\hline
\end{tabular}

While the percent mass of phosphorus in the metal contents of the samples ranged from 1-3\%, the amount that is available for plant uptake or that is water soluble must be considered, this was measured in the form of phosphates $\left(\mathrm{PO}^{-3}{ }_{4}\right)$. Phosphorous, may exist in both organic and inorganic forms (BC Ministry of Environment, 2008). The total and plant available phosphorous may vary. Water soluble phosphorus is the amount of phosphorus that is 
readily available to plants (Fuhrman, Zhang, Schroder, \& Davis, 2005; Nurmesniemi, Manskinen, Poykio, \& Dahl, 2012). Research conducted on wood based biomass in an incinerator reported that the water soluble phosphorus content in bottom ash sample is negligible (Nurmesniemi et al., 2012). The research concluded that the poor water solubility of phosphorus was a draw back in the application of wood ash to soils since only a small portion $\mathrm{P}$ is extractable and available for plants when used in forest fertilizers. Our research showed some amounts of water soluble phosphorus present in the form of phosphates, though low in concentrations (Table 5). The starting ash for the pellet burner and gasifier were $0.83 \mathrm{mg} / \mathrm{kg}$ and $0.08 \mathrm{mg} / \mathrm{kg}$, respectively, while the boiler ash was below the detection limit. Concentrations varied within particle size fractions. The pellet ash ranged from $0.66-3.6 \mathrm{mg} / \mathrm{kg}$; lowest observed in particle size fraction $<150 \mu \mathrm{m}$ and the highest in $425 \mu \mathrm{m}$ fraction. The gasifier ash ranged from $0.1-0.74 \mathrm{mg} / \mathrm{kg}$ for the different fractions. The water soluble phosphate were only detected within the three largest particle size fractions for the boiler ash and ranged between $0.35-2.57 \mathrm{mg} / \mathrm{kg}$. While the three largest fractions of the boiler samples had higher concentrations of phosphorus, water soluble phosphorus were not detected for these fractions. It does suggest that the phosphorus present in these fractions may be insoluble in water.

The presence of relatively high $\mathrm{Ca}$ and $\mathrm{Mg}$, typically in the form of oxides, hydroxides and carbonates, suggests use of these ashes as potential liming agents. This could help in controlling soil $\mathrm{pH}$. As the particle size fraction decreased, the concentrations of $\mathrm{Ca}$ and $\mathrm{Mg}$ increased and so did the $\mathrm{pH}$. Therefore, specific fractions could be used to achieve appropriate liming requirements.

\subsubsection{Inorganic Relationship to Total Carbon Content}

The results were also analysed to identify the possibilities of any relationship that may exist between the elemental distribution of major inorganic components and the total carbon content (James et al., 2013). Figures 3a and 3b show a graphical display of the elements $\mathrm{Ca}$, and $\mathrm{P}$ versus total carbon. These two elements showed a linear correlation for boiler sample; most of the carbon (over 60\%) in this sample was organic carbon. A strong correlation was obtained with $\mathrm{R}^{2}$ value of 0.9272 and 0.9218 for $\mathrm{Ca}$ and $\mathrm{P}$, respectively. The equations are displayed in Equations 1 and 2. As a general trend, as the total carbon content increases the elemental concentrations for $\mathrm{Ca}$ and $\mathrm{P}$ decrease. These equations may help in determining the approximate amount of certain nutrients that may be present in ash. It would be worth removing as much carbon as possible to increase the concentration of nutrients.

$$
\begin{array}{ll}
y=-1969 \mathrm{C}+182159 & R^{2}=0.9272 \\
y-113.92 \mathrm{C}+9973.5 & R^{2}=0.9218
\end{array}
$$

No major trend or correlation was observed when samples from the gasifier and pellet burner were analysed. This may have been due to the very low carbon distribution within the particle size fractions for each sample.

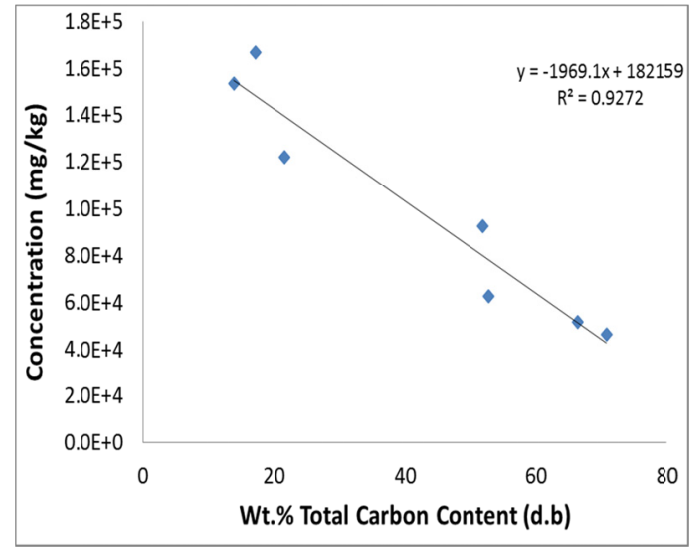

(a)

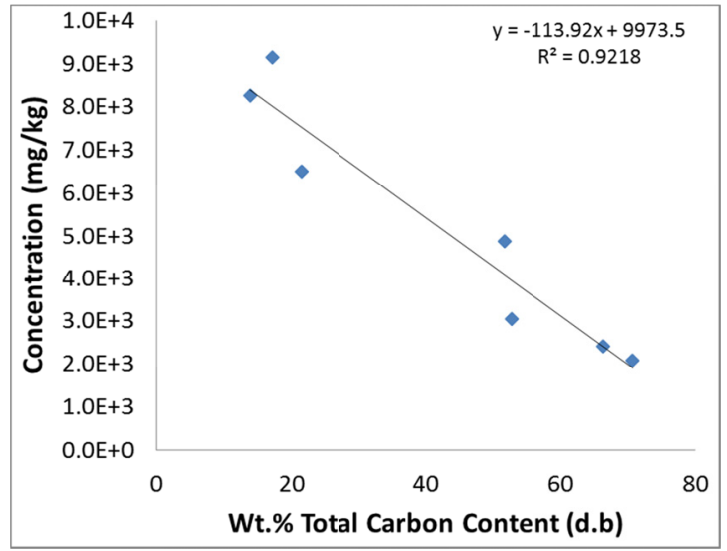

(b)

Figure 3. The correlation of calcium (Ca) and phosphorus (P) concentrations, respectively shown by (a) and (b), as a function of total carbon found in boiler ash

The presence of organic carbon in ash, if recycled to forest soils presents a challenge. Unburned carbon creates a dilution effect which reduces the concentration of inorganic nutrients available in the ash (Sarenbo, 2009). This is 
evident from the two correlations above where the metal content increases with the decreasing carbon contents. If a high concentration of carbon is present in ash, greater amounts of ash will be required to fulfill the nutrients demand by the soil. It should be noted that high carbon ash has also been associated with elevated concentrations of environmentally harmful products of incomplete combustion, such polycyclic aromatic compounds (PAH) (Sarenbo, 2009; Bundt, Krauss, Blaser, \& Wilcke, 2001); other work with these ashes has shown very low concentrations of PAHs, dioxins and furans (data not shown). The presence of carbon also reduces the ability of the ash to harden, which is integral to improving the handling of ashes and reducing its solubility (Sarenbo, 2009). This property limits its application to soil. Perhaps, if suitable methods for recirculating and reburning high carbon ash are determined, higher nutrient concentrations could be obtained while at the same time tackling some of existing ash related issues.

On the other hand, should high carbon ash possess similar properties as biochar then it could be used to obtain positive results in soil applications. Research has shown that biochar addition to soil may enhance properties, increasing plant growth nutrient availability, cation exchange capacity, water retention and with a reduction in the release of some greenhouse gases (Robertson, Rutherford, Lopez-Gutierrez, \& Massicotte, 2012; Laird, 2007; Lehmann, 2007). Further studies are needed to determine if high carbon ash could also have these positive effects.

\section{Conclusion}

The inorganic element contents, $\mathrm{pH}$ and phosphate distribution of wood ash samples obtained from a fixed-bed boiler, fixed-bed gasifier and pellet burner were characterised. The samples showed variations in $\mathrm{pH}$ values both within particle size fractions and across the three systems. The starting ash samples for the gasifier, boiler and pellet burner ash had a $\mathrm{pH}$ of 10.36, 12.49 and 13.46, respectively. The $\mathrm{pH}$ increased with decreasing particle size fractions. This increase in $\mathrm{pH}$ may have been due to the increase in concentrations of the alkali earth metals as the particle size fractions decrease, forming higher concentrations of base-forming metal salts.

The trace element contents for the starting ash samples of the three ash types were all within the environmental limits for soil amendments in British Columbia, Canada. However, when analyzed within particle fractions, Ni with a concentration of $229 \mathrm{mg} / \mathrm{kg}$ from the pellet burner ash, exceeded the limit within the particle size fraction $\geq 850 \mu \mathrm{m}$ but $<2000$. The starting ash samples were significantly enriched in both $\mathrm{Ca}(50-61 \mathrm{wt} . \%)$ and $\mathrm{K}(10-26$ wt.\%) on a total metal composition. The highest values reported for Ca were seen in Pellet burner ash, from $\sim 136,000$ to $\sim 262,000 \mathrm{mg} / \mathrm{kg}$. Very low concentrations of water soluble phosphates were obtained for all ash types in some case below the detection limit. A strong correlation was developed between the total carbon present and the metal contents for $\mathrm{Ca}$ and $\mathrm{P}$.

These results suggest that fraction separation can be a useful method to isolate fractions containing higher amounts of some metals. This method may be a useful technique for elements exceeding environmental exposure limits.

However, the variation in concentrations poses a difficulty in the general application of bottom ash to soils due to the lack of standardization in ash quality. As shown from the research, the inorganic content of the ash samples varied across systems and within fractions. In addition to known factors such as fuel type and temperature, the research showed that other factors such the carbon content and particle size could play a role in determining the concentrations of the available inorganics. It is therefore difficult to determine standard compositions of ash.

\section{Acknowledgments}

We would like to thank the following organizations for their support in conducting this research Canfor Pulp Mill and the University of Northern British Columbia Central Equipment Laboratory. Also, we acknowledge funding support from National Science and Engineering Research Council (NSERC) and Canfor Pulp Limited Partnership (CPLP).

\section{References}

Aronsson, K., \& Ekelund, N. (2004). Biological effects of wood ash application to forest and aquatic ecosytems. Journal of Environmental Quality, 33, 1595-1605. http://dx.doi.org/10.2134/jeq2004.1595

BC Ministry of Environment. (2008). Land application guidelines for the organic matter recycling regulation and the soil amendment code of practice. New Westminister, BC: SYLVIS Environmental.

Bundt, M., Krauss, M., Blaser, B., \& Wilcke, W. (2001). Forest fertilzation with wood ash: effect on the distribution and storage of polycyclic aromatic hydrocarbons (PAHs) and poly choloronated biphenyls (PCBs). Journal of Environmental Quality, 30, 1296-1304. http://dx.doi.org/10.2134/jeq2001.3041296x

Clarholm, M. (1994). Granulated wood ash and a N-free fertilizer to a forest soil-effects on P availability. Forest Ecology and Management, 66, 127-136. http://dx.doi.org/10.1016/0378-1127(94)90152-X 
Dahl, O., Nurmesniemi, H., Poykio, R., \& Watkins, G. (2010). Heavy metal concentrations in bottom ash and fly ash fractions from a large sized (246MW) fluidized bed boiler with repect to their Finnish forest fertilizer limit values. Fuel Processing Technology, 91, 1634-1639. http://dx.doi.org/10.1016/j.fuproc.2010.06.012

Demeyer, A., Voundi-Nkana, J., \& Velow, M. (2001). Characteristics of wood ash and influence on soil properties and nutrient uptake: An overview. Bioresource Technology, 77, 287-295. http://dx.doi.org/10.1016/S0960-8524(00)00043-2

Fuhrman, J., Zhang, H., Schroder, L., \& Davis, R. (2005). Water-soluble phosphorus as affected by soil to extract ratios, extraction times and electrolyte. Communication in soil science and plant analysis, 36, 925-935. http://dx.doi.org/10.1081/CSS-200049482

Hermann, T., \& Baker, S. (2002). Evaluating particle size. Kansas: Kansas State University Agricultural Experiment Station and Cooperative Extension Service.

James, A., Thring, R., Helle, S., \& Rutherford, M. (2013). Characterization of biomass bottom ash from an industrial-scale fixed bed boiler. Energy and Environment Research, 3(2), 21-32. http://dx.doi.org/10.5539/eer.v3n2p21

Kalra, Y., \& Maynard, D. (1991). Methods manual for forest soil and plant analysis. Alberta: Forestry Canada.

Knapp, B., \& Insam, H. (2011). Recycling of biomass ashes: current technologies and future research needs. In H. Insam \& B. A. Knapp (Eds.), Recycling of Biomss Ashes. New York: Springer. http://dx.doi.org/10.1007/978-3-642-19354-5_1

Laird, D. (2007). The charcoal vision: a win-win-win scenario for simultaneously producing bioenergy, permanent sequestering carbon, while improving soil and water quality. Agron. Journal, 100, 178-180. http://dx.doi.org/10.2134/agrojn12007.0161

Lehmann, J. (2007). A handful of carbon. Nature, 447, 143-144. http://dx.doi.org/10.1038/447143a

Liao, C., Wu, C., \& Yan, Y. (2007). The characteristics of inorgani elements in ashes from a 1MW CFB biomass gasification power plant. Fuel Processing Technology, 88, 149-156. http://dx.doi.org/10.1016/j.fuproc.2005.06.008

Misra, M., Ragland, K., \& Baker, A. (1993). Wood ash composition as a funtion of furnace temoperature. Biomass and Bioenergy, 4(2), 103-116. http://dx.doi.org/10.1016/0961-9534(93)90032-Y

Narodoslawsky, M., \& Obernberger, I. (1996). From waste to raw material - the way of cadmium and other heavy metals from biomass to wood ash. Journal of Hazardous Mateials, 50(2-3), 157-168. http://dx.doi.org/10.1016/0304-3894(96)01785-2

Nurmesniemi, H., Manskinen, K., Poykio, R., \& Dahl, O. (2012). Forest fertilizer properties of the bottom ash and fly ash from llarge-sized (115MW) industrial powerplant incinerating wood-based biomass residues. Journal of the Univeristy of Chemical Technology and Metallurgy, 1, 43-52.

Obernberger, I., Biedermann, F., Widmann, W., \& Riedl, R. (1997). Concentrations of inorganic elements in biomass fuels and recovery in different ash fractions. Biomass and Bioenergy, 12, 211-224. http://dx.doi.org/10.1016/S0961-9534(96)00051-7

Obernberger, I., \& Supancic, K. (June/July 2009). Possibillities of ash utilisation from biomass combustion plants. Proceedings of the 17th European Biomass conference \& Exhibition. Hamburg: ETA Renewable Energies.

Pels, J., de Nie, D., \& Kiel, J. (2005). Utilization of ashes from biomass combustion and gasification. Paris, France: Published at 14th European biomass conference \& exhibition.

Picco, D. (February 2010). Technical assistance for the development and improvement of technologies methodologies and tools for enhanced use of agricultural biomass residues. Goriza, IT: C.E.T.A- Centro di Ecologia Teorica ed Applicata.

Robertson, S., Rutherford, M., Lopez-Gutierrez, J., \& Massicotte, H. (2012). Biochar enhances seedling growth and alterss root symbioses and properties of sub-boreal forest soils. Canadian Journal of Soil Science, 92, 329-340. http://dx.doi.org/10.4141/cjss2011-066

Sarenbo, S. (2009). Wood ash dilemma - reduced quality due to poor combustion performance. Biomass and Bioenergy, 33, 1212-1220. http://dx.doi.org/10.1016/j.biombioe.2009.05.007 
Steenari, B., Karlsson, L., \& Lindqvist, O. (1999). Evaluation of the leaching characteristics of wood ash and the influence of ash agglomeration. Biomass and Bioenergy, 16, 119-136. http://dx.doi.org/10.1016/S0961-9534(98)00070-1

Stupak, I., Asikainen, A., Roser, D., \& Pasanen, K. (2008). Review of recommnedation for forest energy harvesting and wood ash recycling. In D. Roser, A. Asaikainen, K. Raulund-Rasmussen \& I. Stupak (Eds.), Sustainable Use of Forest Biomass for Energy. Heidelberg: Springer. http://dx.doi.org/10.1007/978-1-4020-5054-1_7

Vance, E. (1996). Land application of wood-fired and combustion boiler ashes: an overview. Journal of Environmental Quality, 25, 937-944. http://dx.doi.org/10.2134/jeq1996.00472425002500050002x

\section{Copyrights}

Copyright for this article is retained by the author(s), with first publication rights granted to the journal.

This is an open-access article distributed under the terms and conditions of the Creative Commons Attribution license (http://creativecommons.org/licenses/by/3.0/). 